\section{BRAZIULIAN JOURNAL \\ OF MEDICAL AND BIOLOGICAL RESF.ARCH}

www.bjournal.com.br
ISSN 0100-879X

Volume 42 (12) 1119-1247 December 2009

BIOMEDICAL SCIENCES

AND

CLINICAL INVESTIGATION

Braz J Med Biol Res, December 2009, Volume 42(12) 1163-1166

The effect of thyroid hormones on the white adipose tissue gene expression of PAl-1 and its serum concentration

C. Biz, C. Oliveira, A.B.M. Mattos, J. Oliveira1, E.B. Ribeiro, C.M. Oller do Nascimento and L.M. Oyama

The Brazilian Journal of Medical and Biological Research is partially financed by
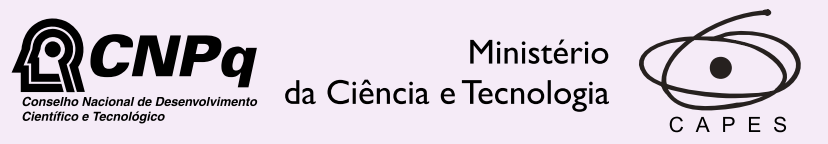

Ministério da Educação
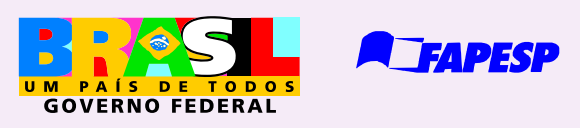

Institutional Sponsors 


\title{
The effect of thyroid hormones on the white adipose tissue gene expression of PAl-1 and its serum concentration
}

\author{
C. Biz ${ }^{1}$, C. Oliveira ${ }^{1}$, A.B.M. Mattos ${ }^{1}$, J. Oliveira ${ }^{1}$, E.B. Ribeiro ${ }^{1}$, \\ C.M. Oller do Nascimento ${ }^{1}$ and L.M. Oyama ${ }^{2}$ \\ ${ }^{1}$ Disciplina de Fisiologia da Nutrição, Departamento de Fisiologia, \\ Universidade Federal de São Paulo, São Paulo, SP, Brasil \\ 2Departamento de Biociências, Universidade Federal de São Paulo, Santos, SP, Brasil
}

\begin{abstract}
Metabolic syndrome is associated with an increased risk of developing cardiovascular diseases and plasminogen activator inhibitor 1 (PAl-1) overexpression may play a significant role in this process. A positive correlation between adipose tissue gene expression of PAI-1 and its serum concentration has been reported. Furthermore, high serum levels of thyroid hormones (T3 and T4) and PAI-1 have been observed in obese children. The present study evaluates the impact of thyroid hormone treatment on white adipose tissue PAl-1 gene expression and its serum concentration. Male Wistar rats (60 days old) were treated for three weeks with T4 (50 $\mu \mathrm{g} / \mathrm{day}$, Hyper) or with saline (control). Additionally, 3T3-L1 adipocytes were treated for $24 \mathrm{~h}$ with T4 (100 nM) or T3 (100 nM). PAl-1 gene expression was determined by real-time PCR, while the serum concentration of PAl-1 was measured by ELISA using a commercial kit (Innovative Research, USA). Both the serum concentration of PAI-1 and mRNA levels were similar between groups in retroperitoneal and epididymal white adipose tissue. Using 3T3-L1 adipocytes, in vitro treatment with T4 and T3 increased the gene expression of PAI-1, suggesting non-genomic and genomic effects, respectively. These results demonstrate that thyroid hormones have different effects in vitro and in vivo on PAl-1 gene expression in adipocytes.
\end{abstract}

Key words: Thyroid hormones; Plasminogen activator inhibitor 1; White adipose tissue; 3T3-L1

\section{Introduction}

Adipose tissue has an essential energy storage function due to its triacylglyceride reserve but is now also recognized to be an important secretory organ. Adipose tissue produces the adipokines involved in glucose tolerance and insulin sensitivity (adiponectin, TNF- $\alpha$, interleukin-6, and resistin), vascular homeostasis (plasminogen activator inhibitor 1, PAI-1), and inflammatory and stress responses (TNF- $\alpha$, interleukin-6, haptoglobin, and metallothionein), among others (1).

$\mathrm{PAl}-1$ is the main inhibitor of the fibrinolytic system, which is formed by several proteins that regulate plasmin generation, whose function is to cleave fibrin and to activate extracellular matrix-metalloproteinases, further eliminating fibrin clots (2). Fibrin clot formation in the endothelial lesion site is a critical process in the maintenance of vascular integrity. Increasing evidence indicates that higher plasma PAI-1 levels induce the development of thromboembolytic complications (3) and cardiovascular disease. Adipose tissue PAl-1 gene expression and serum concentration have been reported in several pathological conditions, such as obesity, hyperinsulinemia, and hyperglycemia $(4,5)$.

The thyroid hormones T4 (thyroxin) and T3 (triiodothyronine) also have cardiovascular effects, probably through the regulation of circulating clotting proteins and fibrinolytic activity (6); however, the mechanisms leading to cardiovascular and thromboembolytic diseases in thyroid dysfunction are controversial. Some reports have described an increase in serum PAI-1 concentration in hyperthyroidism, whereas others did not detect any differences (7-9).

In the present study, we determined the effects of in vivo treatment of rats with the thyroid hormone T4 on gene expression and the serum concentration of PAI-1. Additionally, the effects of T3 and T4 on the gene expression of PAI-1 in 3T3-L1 adipocytes were also evaluated.

Correspondence: C.M. Oller do Nascimento, Departamento de Fisiologia, UNIFESP, Rua Botucatu, 862, $2^{\circ}$ andar, 04023-062 São Paulo, SP, Brasil. Fax: +55-11-5573-9525. E-mail: claudia.oller@unifesp.br

Received May 16, 2009. Accepted November 4, 2009. Available online November 13, 2009. Published December 4, 2009. 


\section{Material and Methods}

\section{Animals and treatments}

Male Wistar rats (60 days old) were obtained from the Universidade Federal de São Paulo, Centro de Desenvolvimento de Modelos Experimentais (CEDEME). They were maintained in the animal house of the Division of Nutrition Physiology, under controlled conditions of light (12-h light/ dark cycle, lights on at $6 \mathrm{am}$ ) at $22 \pm 1^{\circ} \mathrm{C}$, and with free access to food and water. Care and use of the laboratory animals were in accordance with $\mathrm{NIH}$ guidelines and the local Ethics Committee at Universidade Federal de São Paulo (protocol \#0079/07).

The rats were allowed to acclimatize for 1 week before the beginning of the experiment, and then were randomly divided into 2 groups: 1) control group that received a daily intraperitoneal (ip) injection of vehicle $(\mathrm{N}=10)$, and 2) hyperthyroid rat group (Hyper) that received a daily ip injection of T4 (50 mg/rat; $\mathrm{N}=10)(10)$.

The animals received a diet prepared according to the recommendations of the American Institute of Nutrition (AIN-93M) (11). This diet was composed of casein (14\%), cornstarch $(71.1 \%)$, soybean oil $(5 \%)$, non-nutritive cellulose fiber (5\%), AIN-93 mineral mix (3.5\%), AIN-93 vitamin mix (1\%), choline bitartrate $(0.25 \%)$, L-cystine $(0.18 \%)$, butylhydroquinone $(0.0008 \%)$, and energy $(3.8 \mathrm{kcal} / \mathrm{g})$. Body weight and food intake were measured weekly.

\section{Experimental procedures}

All animals were treated and fed for 21 days. Euthanasia was performed in the fed condition by decapitation without sedation. Trunk blood was collected and immediately centrifuged, and serum was stored at $-80^{\circ} \mathrm{C}$ before the determination of $\mathrm{T} 4, \mathrm{~T} 3$, and $\mathrm{PAI}-1$. The retroperitoneal (RET) and epididymal (EPI) white adipose tissues were removed completely and weighed, immediately frozen in liquid nitrogen, stored at $-80^{\circ} \mathrm{C}$, and finally used for PAI-1 mRNA quantification.

\section{Cell culture}

3T3-L1 cells were obtained from the American Type Culture Collection and cultured at $37^{\circ} \mathrm{C}$ in a humidified atmosphere of $5 \% \mathrm{CO}_{2} / 95 \%$ air. The cells were grown in Dulbecco's modified Eagle's medium (Invitrogen, USA) containing $25 \mathrm{mM}$ glucose, $1 \mathrm{mM}$ pyruvate, $4.02 \mathrm{mM} \mathrm{L}-$ alanyl-glutamine, and $10 \%$ fetal calf serum (Sigma, USA). Differentiation of the cells was initiated $24 \mathrm{~h}$ after confluence by incubation in a growth medium containing $0.25 \mu \mathrm{M}$ dexamethasone, $0.5 \mathrm{mM} 3$-isobutyl-1-methyl-xanthine, and $5 \mu \mathrm{g} / \mathrm{mL}$ insulin (Sigma) for 2 days. This was followed by 10 days in a growth medium containing $5 \mu \mathrm{g} / \mathrm{mL}$ insulin. On the 10th day, fetal calf serum was removed for $6 \mathrm{~h}$ and the adipocytes were then treated for $24 \mathrm{~h}$ with $100 \mathrm{nM}$ T3 $(\mathrm{N}=$ 12) or $100 \mathrm{nM} \mathrm{T4}(\mathrm{N}=12)(12)$. In the control group $(\mathrm{N}=$ 12 ), the medium was changed, but no agent was added.

\section{RNA extraction and real-time polymerase chain reaction}

Total RNA was isolated from RET and EPI samples using Trizol (Invitrogen) following manufacturer recommendations. Concentrations of RNA were determined by measuring absorbance at $260 \mathrm{~nm}$. The purity of RNA was determined by calculating the absorbance ratios at 260 and $280 \mathrm{~nm}$, as well as by electrophoresis on an ethidium bromide-stained gel.

PAI-1 mRNA from RET and EPI and 3T3-L1 cells were quantified by real-time PCR. RNA samples were previously treated with DNAse (DNAfree, Promega, USA). One microgram of each sample was reverse transcribed using an M-MLV reverse transcriptase kit (Promega), and cDNA was synthesized in a final volume of $50 \mu \mathrm{L}$. The relative level of PAl-1 mRNA was quantified in real time using the SYBR green primer in an ABI Prism 7700 Sequence detector (both from Applied Biosystems, USA). The relative level of the housekeeping gene hypoxanthine phosphoribosyltransferase (HPRT) was measured. The primers used included PAI-1 rat forward GACAATGGAAGAGCAACATG and reverse ACCTCGATCTTGACCTTTTG, PAI-1 mouse forward ACAGCCTTTGTCATCTCAGCC and reverse CCGAACCACAAAGAGAAAGGA, and HPRT forward CTC ATGGACTGATTATGGACAGGAC and reverse GCAGG TCAGCAAAGAACTTATAGCC.

Data were obtained using a sequence detector software (Applied Biosystems) and are reported as relative increase using the method of $2^{-\Delta \Delta C t}(13)$.

\section{Biochemical and hormonal serum analysis}

Serum T3 and T4 concentrations were quantified using specific chemiluminescent immunometric assays (Advia Centaur, Bayer Corporation, USA). PAI-1 serum concentration was determined using a commercial kit (Innovative Research, USA).

\section{Statistical analysis}

Data are reported as means \pm SEM. Statistical significance was assessed by the Student $t$-test for unpaired samples. Differences were considered to be significant when $\mathrm{P}<0.05$.

\section{Results}

During the 3-week treatment period, the Hyper group treated with $\mathrm{T} 4$ presented an increased energy intake when compared to the control group. Both groups gained body weight during treatment, but the control group gained more weight (Table 1). However, the weights of retroperitoneal and epididymal adipose tissues were not different (Table 1). In order to validate this protocol, we quantified the thyroid hormones in the serum of treated animals. As shown in Table 1, thyroxine injection increased both T4 and T3 serum concentrations (Hyper) when compared to those of 
saline-treated rats (control).

$\mathrm{PAl}-1$ gene expression in epididymal and retroperitoneal adipose tissues and PAI-1 serum concentrations was similar in both the Hyper and control groups (Table 1); however, in 3T3-L1 adipocytes, treatment with T4 or T3 for $24 \mathrm{~h}$ increased PAl-1 gene expression 1.6 and 1.9 times, respectively (Figure 1).

\section{Discussion}

The results of the present study show that thyroid hormones stimulate the expression of the PAl-1 gene in 3T3-L1 cells; however, we did not observe changes in adipose tissue gene expression of PAI-1 in vivo, despite the increase of T4 and T3 serum concentrations.

Numerous studies have shown that thyroid hormones increase the metabolic rate and accelerate practically all metabolic pathways, with a consequent increase in ATP turnover and heat production (14); however, in the present study, treatment with T4 for 3 weeks did not modify the adiposity of the animals, as shown by unchanged adipose tissue weights. This could be explained by the increase in energy intake observed in the Hyper group (T4-treated animals) in comparison to the control group. In fact, it has been recently reported that T4 treatment increases food intake (15).

In our model, the in vivo T4 treatment did not modify PAl-1 gene expression in RET and EPI, or in serum PAI-1 concentration. On the other hand, the addition of T3 or T4 to the culture medium caused an increase in PAl-1 gene expression in 3T3-L1 adipocytes. As far as we know, no investigation has reported the presence of deiodinase (the enzyme that converts T4 to T3) in 3T3-L1 adipocytes, suggesting non-genomic (T4 effect) and genomic ef- fects (T3 effect) of thyroid hormones on PAI-1 expression in these cells.

These results demonstrate that adipocytes present different responses to thyroid hormones when considering in vivo and in vitro experiments. Other investigations have also demonstrated different in vivo and in vitro responses. Growth hormone treatment has been reported to increase PAI-1 secretion by 3T3-L1 adipocytes (16) and to decrease $\mathrm{PAl}-1$ serum concentration in vivo (17). Similarly, the ingestion of an n-3 PUFA-enriched diet for 60 days did not affect adiponectin gene expression or serum adiponectin concentration in vivo, whereas treatment with eicosapentaenoic and docosahexaenoic fatty acids decreased adiponectin mRNA levels in 3T3-L1 adipocytes (18).

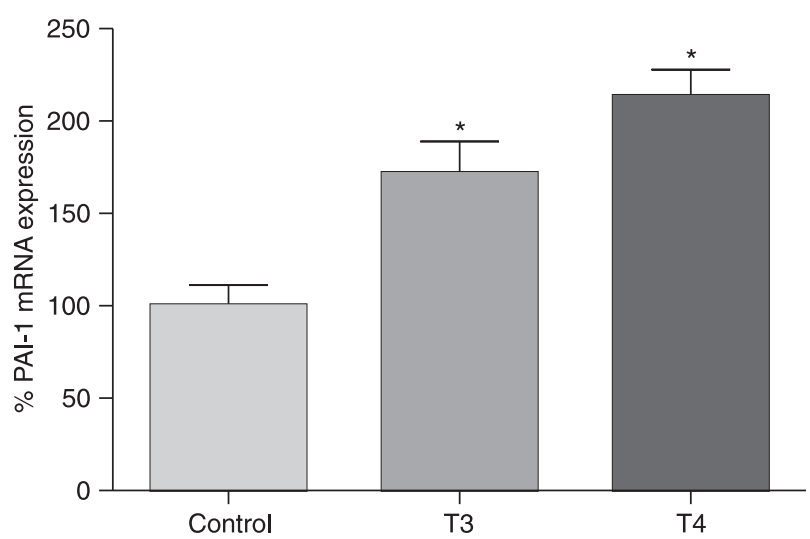

Figure 1. PAl-1 gene expression by 3T3-L1 adipocytes treated for $24 \mathrm{~h}$ with T4 or T3 ( $\mathrm{N}=12$ /group). Data (means $\pm \mathrm{SEM}$ ) are reported as a percentage of the control group. ${ }^{*} \mathrm{P}<0.05 \mathrm{vs}$ control group (unpaired Student $t$-test).

Table 1. Body weight gain, energy intake, weight of retroperitoneal and epididymal adipose tissue, serum concentrations of T4 and T3, PAI-1 gene expression in retroperitoneal and epididymal adipose tissues, and serum concentration in rats treated with saline (control) or T4 (Hyper).

\begin{tabular}{lcc}
\hline & Control & Hyper \\
\hline Body weight gain (g) & $88.4 \pm 11.0$ & $60.9 \pm 7.8^{*}$ \\
Energy intake (kcal/3 weeks) & $524.9 \pm 41.3$ & $679.9 \pm 48.8^{*}$ \\
Retroperitoneal adipose tissue (g) & $4.2 \pm 0.5$ & $3.4 \pm 0.4$ \\
Epididymal adipose tissue (g) & $4.0 \pm 0.3$ & $3.9 \pm 0.4$ \\
3,3'5-Triiodothyronine (T3) (ng/dL) & $87.0 \pm 6.4$ & $438.4 \pm 39.5^{*}$ \\
Thyroxine (T4) (mg/dL) & $4.4 \pm 0.5$ & $17.1 \pm 0.6^{*}$ \\
PAl-1 gene expression in retroperitoneal adipose tissue (\%) & $100.0 \pm 12.4$ & $70.9 \pm 12.8$ \\
PAl-1 gene expression in epididymal adipose tissue (\%) & $100.0 \pm 10.8$ & $72.7 \pm 14.9$ \\
PAl-1 serum concentration (pg/mL) & $104.8 \pm 9.1$ & $65.8 \pm 11.8$ \\
\hline
\end{tabular}

Data are reported as means \pm SEM for 10 animals per group. ${ }^{*} \mathrm{P}<0.05$ vs control group (unpaired Student $t$-test). 
The diverse in vivo and in vitro effects of thyroid hormones on PAl-1 gene expression regulation are not related to the inhibitory effect of T4 on thyroid-stimulating hormone (TSH) secretion, since the literature has not shown any relationship between TSH and PAI-1 serum concentration (19). However, it could be suggested that the lower amount of thyroid hormone receptors and deiodinase present in white adipose tissue than in brain, liver, brown adipose tissue, and kidney may be involved in this process.

In addition, the low blood flow in white adipose tissue in comparison to other tissue types (20) could contribute to hormone distribution in vivo, suggesting that lower amounts of T4 and T3 were achieved in adipocytes in vivo in com-

\section{References}

1. Trayhurn P, Beattie JH. Physiological role of adipose tissue: white adipose tissue as an endocrine and secretory organ. Proc Nutr Soc 2001; 60: 329-339.

2. Fay WP, Garg N, Sunkar M. Vascular functions of the plasminogen activation system. Arterioscler Thromb Vasc Biol 2007; 27: 1231-1237.

3. Seki T, Miyasu T, Noguchi T, Hamasaki A, Sasaki R, Ozawa $Y$, et al. Reciprocal regulation of tissue-type and urokinasetype plasminogen activators in the differentiation of murine preadipocyte line 3T3-L1 and the hormonal regulation of fibrinolytic factors in the mature adipocytes. $J$ Cell Physiol 2001; 189: 72-78.

4. Sudi KM, Gallistl S, Trobinger M, Payerl D, Weinhandl G, Muntean W, et al. The influence of weight loss on fibrinolytic and metabolic parameters in obese children and adolescents. J Pediatr Endocrinol Metab 2001; 14: 85-94.

5. Alessi MC, Poggi M, Juhan-Vague I. Plasminogen activator inhibitor-1, adipose tissue and insulin resistance. Curr Opin Lipidol 2007; 18: 240-245.

6. Horne MK III, Singh KK, Rosenfeld KG, Wesley R, Skarulis $\mathrm{MC}$, Merryman PK, et al. Is thyroid hormone suppression therapy prothrombotic? J Clin Endocrinol Metab 2004; 89: 4469-4473.

7. Erem C, Ersoz HO, Karti SS, Ukinc K, Hacihasanoglu A, Deger $\mathrm{O}$, et al. Blood coagulation and fibrinolysis in patients with hyperthyroidism. J Endocrinol Invest 2002; 25: 345350.

8. Li Y, Chen H, Tan J, Wang X, Liang H, Sun X. Impaired release of tissue plasminogen activator from the endothelium in Graves' disease - indicator of endothelial dysfunction and reduced fibrinolytic capacity. Eur J Clin Invest 1998; 28: 1050-1054.

9. Wahrenberg H, Wennlund A, Hoffstedt J. Increased adipose tissue secretion of interleukin-6, but not of leptin, plasminogen activator inhibitor-1 or tumour necrosis factor alpha, in Graves' hyperthyroidism. Eur J Endocrinol 2002; 146: 607611.

10. Rodriguez-Gomez I, Wangensteen R, Moreno JM, Chamorro V, Osuna A, Vargas F. Effects of chronic inhibition of inducible nitric oxide synthase in hyperthyroid rats. Am J Physiol parison to the in vitro study.

This study demonstrates that thyroid hormones have different effects in relation to PAl-1 gene expression in adipocytes in the intact rat (in vivo study) and in cultured adipocytes (in vitro study). Further studies are required to better elucidate the diverse in vivo and in vitro effects of thyroid hormone on adipocytes PAl-1 gene expression.

\section{Acknowledgments}

The authors would like to thank Mr. Valter Tadeu Boldarine for technical assistance and Mauro Cardoso for animal care. Research supported by FAPESP (\#2006/58628-1).

Endocrinol Metab 2005; 288: E1252-E1257.

11. Reeves PG, Nielsen FH, Fahey GC Jr. AIN-93 purified diets for laboratory rodents: final report of the American Institute of Nutrition ad hoc Writing Committee on the reformulation of the AIN-76A rodent diet. J Nutr 1993; 123: 1939-1951.

12. Yoshida T, Monkawa T, Hayashi M, Saruta T. Regulation of expression of leptin mRNA and secretion of leptin by thyroid hormone in 3T3-L1 adipocytes. Biochem Biophys Res Commun 1997; 232: 822-826.

13. Livak KJ, Schmittgen TD. Analysis of relative gene expression data using real-time quantitative PCR and the 2(-Delta Delta C(T)) method. Methods 2001; 25: 402-408.

14. Silva JE. The thermogenic effect of thyroid hormone and its clinical implications. Ann Intern Med 2003; 139: 205-213.

15. Ishii $S$, Kamegai J, Tamura $H$, Shimizu T, Sugihara $H$, Oikawa S. Triiodothyronine (T3) stimulates food intake via enhanced hypothalamic AMP-activated kinase activity. Regul Pept 2008; 151: 164-169.

16. Kralisch S, Klein J, Lossner U, Bluher M, Paschke R, Stumvoll $\mathrm{M}$, et al. Plasminogen activator inhibitor-1 expression and secretion are stimulated by growth hormone and interleukin-6 in 3T3-L1 adipocytes. Mol Cell Endocrinol 2006; 253: $56-62$

17. Ahn CW, Kim CS, Nam JH, Kim HJ, Nam JS, Park JS, et al. Effects of growth hormone on insulin resistance and atherosclerotic risk factors in obese type 2 diabetic patients with poor glycaemic control. Clin Endocrinol 2006; 64: 444-449.

18. Bueno AA, Oyama LM, de Oliveira C, Pisani LP, Ribeiro EB, Silveira VL, et al. Effects of different fatty acids and dietary lipids on adiponectin gene expression in 3T3-L1 cells and C57BL/6J mice adipose tissue. Pflugers Arch 2008; 455: 701-709.

19. Donnini D, Ambesi-Impiombato FS, Curcio F. Thyrotropin stimulates production of procoagulant and vasodilative factors in human aortic endothelial cells. Thyroid 2003; 13: 517-521.

20. Closa D, Gomez-Sierra JM, Latres E, Alemany M, Remesar $X$. Short-term oscillations of aortic core temperature and thermogenic organ blood flow in the rat. Exp Physiol 1993; 78: 243-253. 